JACEK WAŁDOCH

\title{
Sprawa lwowskiego samorządu miejskiego przed Najwyższym Trybunatem Administracyjnym w 1929 r.
}

\author{
Abstract \\ The Case of Lviv Municipal Government in the Supreme Administrative \\ Tribunal in 1929
}

This article is devoted to the issue of the dissolution of the Lviv City Council and the matter considered by the Supreme Administrative Tribunal in 1929. On August 31 $1^{\text {st }}, 1927$, the Lviv voivode dissolved the Provisional City Council, transferring power over the city to the executive body and a 32-person Adjutant Council. The decision to dissolve the Provisional City Council was widely discussed in political circles, where its legality was questioned. In this regard, the councilors of the Provisional City Council decided to lodge a complaint to the Supreme Administrative Tribunal, which considered the case two years later, in 1929. The representatives of the dissolved Provisional City Council presented a number of arguments, pointing out errors in the voivode's decision and defective supervisory proceedings. Proxies of the dissolved Provisional City Council requested the annulment of the voivode's decision. The verdict in the case was issued on November $28^{\text {th }}, 1929$ and concerned the formal shortcomings of the dissolution of the Provisional City Council. It was demonstrated that its content did not include information on available remedies, in breach of the rules of administrative procedure. The judgment had specific legal and political effects, while the whole case illustrates the attitude of the supervisory authority to the local government.

Keywords: Lviv, local government, Supreme Administrative Tribunal, Second Polish Republic, interwar period

Słowa kluczowe: Lwów, samorząd terytorialny, Najwyższy Trybunał Administracyjny, II Rzeczpospolita, okres międzywojenny

Samorząd miejski Lwowa stanowi jaskrawy przykład tego, z jakimi trudnościami musiały zmierzyć się władze centralne oraz samorządy w trakcie procesu kształtowania ich ustroju w okresie międzywojennym. Rzeczpospolita, stanowiąca zlepek odziedziczonych po zaborcach odmiennych porządków i kultur prawnych, zmuszała rządzących do lawirowania między koniecznością wszczęcia procesu unifikacyjnego, własnymi 
aspiracjami politycznymi a oczekiwaniami opinii publicznej. Ważny moment procesu formowania ustroju samorządu lwowskiego przypadł na koniec lat dwudziestych XX w., kiedy rozwiązanie Tymczasowej Rady Miejskiej spotkało się ze zdecydowaną reakcją samorządowców skarżących decyzję władzy nadzorczej do Najwyższego Trybunału Administracyjnego (NTA). Rozpatrywanie tej sprawy przed NTA stanowiło okazję do refleksji nad dotychczasową formą organizacyjną lwowskiego samorządu miejskiego, która oddziaływała na późniejsze decyzje władzy nadzorczej, stanowiąc przy tym przedmiot szerokiej dyskusji.

Samorząd miejski Leopolis w kształcie, który znany był w chwili wcielenia miasta do granic Rzeczypospolitej w 1918 r., swoją genezę zawdzięcza wydarzeniom z drugiej połowy XIX w., kiedy w wyniku odwilży politycznej Leopolis zyskała szeroki samorząd, wprowadzony 14 października $1870 \mathrm{r}$. na podstawie statutu miejskiego'. W tym kształcie ustrój miejski Lwowa przetrwał do I wojny światowej, która wyznaczyła nowy rozdział w historii lwowskiego samorządu, kiedy miasto na blisko rok znalazło się pod panowaniem rosyjskim. Przed zajęciem Lwowa przez Rosjan wyjechał z niego prezydent Józef Neumann², jego zaś stanowisko w dniu 31 sierpnia 1914 r. przejął wiceprezydent Tadeusz Rutowski ${ }^{3}$. Po opuszczeniu Lwowa przez Rosjan i internowaniu T. Rutowskiego ${ }^{4}$ namiestnik w dniu 30 czerwca 1915 r. podjął decyzję o rozwiązaniu Rady Miejskiej, mianując Adama Grabowskiego komisarzem rządowym ${ }^{5}$. Z powołanej Rady Przybocznej ${ }^{6}$ wybrano następnie dwóch wiceprezydentów: Tadeusza Rutowskiego (pozostającego wtedy w Rosji) oraz Karola Eplera ${ }^{7}$. Zgodnie z przepisami Statutu po rozwiązaniu Rady Miejskiej w ciągu sześciu tygodni miały się odbyć wybory, do tego zaś czasu sprawami miasta zajmować się powinien prezydent i wiceprezydenci. Statut wyraźnie określał, że wyboru pierwszego wiceprezydenta dokonywali „,złonkowie nowo wybranej Rady Miejskiej”, zatem Rada Przyboczna, stanowiąca jedynie organ tymczasowy i doradczy, nie dysponowała kompetencjami do wyboru składu Magistratu. Najwidoczniej namiestnik działał pod presją zarówno czasu, jak i polityczną, stosując jedynie półśrodki w celu uregulowania spraw samorządowych Lwowa. Przyszłość wkrótce pokazała, że prowizoryczne rozwiązania stały się długotrwałe.

Rutowski po powrocie z niewoli, 12 lutego 1917 r., został nowym komisarzem rządowym. Ze względu na zły stan zdrowia był nim krótko i rezygnował blisko rok później, 11 marca 1918 r., na 19 dni przed swoją śmiercią, zarząd nad miastem objął nowy ko-

${ }^{1}$ Ostaszewski-Barański, „Ustawa Prowizoryczna”, 48; Statut król.[ewskiego] [...] 1874; Hołuj, „Samorząd miejski”, 90.

${ }^{2}$ Bohdan, 293 dni rzadów rosyjskich, 57, 74; Biedrzycka, Kalendarium, 15.

${ }^{3}$ O Tadeuszu Rutowskim szerzej zob. U ratuszi, 44-45; Kulmatycki, Rada, 8.

${ }^{4}$ Zob. Białynia-Chołodecki, Zakładnicy, 21.

${ }^{5}$ Sprawozdanie z czynności, 4.

${ }^{6}$ W skład Rady Przybocznej weszli: ks. Henryk Badeni, Jakub Beiser, Marceli Chlamtacz, Karol Epler, Izydor Gromnicki, Dionizy Howarth, Szczepan Mikołajski, Ferdynand Ohly, Józef Onyszkiewicz, Janusz Przygodzki, Salomon Ruff, Tadeusz Rutowski, Henryk Sawczyński, Filip Schleicher, Adam Schneider, Karol Sklepiński, Władysław Stesłowicz i Ludwik Winiarz. Zob. Sprawozdanie z czynności, 4-5.

${ }^{7}$ Ze względu na nieobecność T. Rutowskiego pierwszym zastępcą prezydenta był K. Epler. Po powrocie z niewoli rosyjskiej trzecim wiceprezydentem Lwowa został Filip Schleicher, który objął urząd w dniu 27 XII 1916 r. Zob. Sprawozdanie z czynności, 4; Z.W. „W walce z dyktaturą”, 5. 
misarz w osobie Władysława Stesłowicza ${ }^{8} .31$ stycznia 1918 r. ${ }^{9}$ Namiestnictwo zdecydowało o powołaniu stuosobowej Tymczasowej Rady Miejskiej ${ }^{10}$, która miała zastąpić Radę Przyboczną. Nowa Rada posiadała takie kompetencje, jak ta pochodząca z wyborów ${ }^{11}$, a jej uchwały stały się dla komisarza wiążące ${ }^{12}$. Sprawiało to, że wykroczono poza ustalenia statutowe, nie przewidziano bowiem sytuacji, w której namiestnik mógłby powołać Radę Miejską, chyba że odwołał się on do zasady „ogólnego nadzoru”. Nie zmienia to jednak faktu, że nie rozpisano wyborów miejskich w wyznaczonym przez Statut terminie ${ }^{13}$.

Okres całkowicie polskiego zarządu nad Lwowem rozpoczął się po I wojnie światowej, kiedy 22 listopada 1918 r. miasto ponownie stało się częścią odradzającej się Rzeczypospolitej. Władzę w tak zwanej Galicji Wschodniej objął Tymczasowy Komitet Rządzący (dalej: TKR) ${ }^{14}$, który utrzymał w mocy obowiązującej wszystkie austriackie akty prawne odnoszące się do Galicji, w tym lwowski Statut miejski ${ }^{15}$, a prace nad nową ordynacją wyborczą miała kontynuować specjalna komisja, powołana jeszcze 21 marca $1918 \mathrm{r}^{16}$

Tymczasowy Komitet Rządzący rozwiązano 10 stycznia 1919 r., Generalna Delegatura Rządu funkcjonowała zaś do 1 września 1921 r., kiedy dokonano faktycznego podziału Galicji na województwa: lwowskie, krakowskie, stanisławowskie oraz tarnopolskie ${ }^{17}$. Niejasne są wydarzenia z 11 stycznia 1919 r., kiedy TKR, korzystając z kompetencji prawodawczych, zdecydował o powiększeniu składu Tymczasowej Rady Miejskiej do 150 osób, przyznając jej jednocześnie prawa Rady Miejskiej pochodzącej z wyborów. Po raz kolejny zwlekano z rozpisaniem wyborów samorządowych, wprowadzając organ tymczasowy, a ponadto wprost ingerowano w przepisy Statutu miejskiego ${ }^{18}$. Wydarzenie to stało się przedmiotem szerokich dyskusji pod koniec lat dwudziestych XX w., w kontekście rozwiązania Tymczasowej Rady Miejskiej.

Komisarz Władysław Stesłowicz w dniu 6 lutego 1919 r. zrezygnował z urzędu z powodu powierzenia mu mandatu poselskiego do Sejmu Ustawodawczego ${ }^{19}$, a jego obowiązki przejął Marceli Chlamtacz ${ }^{20}$. Wybór prezydenta przeprowadzono 17 lutego i po trzykrotnym głosowaniu ostatecznie został nim Józef Neumann ${ }^{21}$. Przy okazji

U ratuszi, 44; PAOL, f. 2, op. 26, spr. 11, k. 34; „Kronika. W biurze”, 4; „Zarząd miasta Lwowa, 4.

9 Przemówienia, 19.

${ }^{10}$ Kompletna lista członków Tymczasowej Rady Miejskiej zob. „Tymczasowa Rada Miejska”, 4.

11 PAOL, f. 2, op. 26, spr. 11, k. 27-27v.

12 „Tymczasowa Rada Miejska”, 3-4.

13 Statut król.[ewskiego] stoł.[ecznego] [...] 1930, 69.

14 Biedrzycka, Kalendarium, 2-3.

15 „Rozporządzenie”, 1; Z.W. „W walce z dyktaturą magistracką. Prawdziwa historia”, 5. Statut został następnie nieznacznie zmodyfikowany na podstawie Ustawy z dnia 26 lipca 1919 r. zmieniającej postanowienia galicyjskiej ustawy gminnej, obowiązująca na terytorium b. Galicji (Dz.U. 1919 nr 67 poz. 403).

16 Po zwiększeniu liczby radnych rozszerzono też komisję z 25 do 41 członków i ich 37 zastępców. Z.W., „W walce z dyktaturą magistracką. Lustracja T.W.S., 3.

17 Rozporządzenie (Dz.U. $1921 \mathrm{nr} 46$ poz. 282).

18 Biedrzycka, Kalendarium, 11.

19 PAOL, f. 2, op. 26, spr. 8, k. 105.

20 Biedrzycka, Kalendarium, 14.

${ }^{21}$ Radny Julian Smulikowski wniósł protest co do ważności wyboru prezydenta, ponieważ ten, według J. Smulikowskiego, nie uzyskał wymaganej większości głosów. W przepisach ordynacji stwierdzono, że „,do 
wyborów do Magistratu przestano kontestować tryb powołania nowej Tymczasowej Rady Miejskiej. Warto przy tym nadmienić, że skład Rady Miejskiej od wyborów przeprowadzonych jeszcze przed I wojną światową niemal nie uległ zmianie, co w późniejszych latach było krytykowane przez opinię publiczną i publicystów piszących o „dyktaturze magistrackiej”22.

Powstały po likwidacji Wydziału Krajowego Tymczasowy Wydział Samorządowy ${ }^{23}$ przeprowadził w 1924 r. kontrolę lwowskiego Magistratu, której raport końcowy z 20 maja 1924 r. potwierdzał liczne nieprawidłowości w działaniu urzędu ${ }^{24}$. Dwa lata później przeprowadzono ponowną lustrację celem sprawdzenia wykonania zaleceń pokontrolnych. Wyniki tego badania okazały się pomyślne dla Magistratu, stwierdzono bowiem, że „przeważnie wszystkie usterki i niedomagania [...] zostały usunięte; gospodarka gminy weszła na właściwe tory $[\ldots]]^{\prime 25}$. Mimo pochlebnej opinii lustratorów w 1927 r. mówiło się o rzekomych planach Rządu dążącego do rozwiązania organów miejskich $^{26}$, dlatego Tymczasowa Rada Miejska próbowała wyprzedzić ruch władz centralnych, uchwalając w dniu 13 stycznia 1927 r. wniosek o rozpisanie wyborów na podstawie "nowoczesnego i demokratycznego prawa wyborczego" ${ }^{27}$. Bezskutecznie, ponieważ Magistrat objęto kolejną lustracją, o której nawet nie poinformowano prezydenta miasta i nie przedstawiono mu raportu. Lustracja niosła z sobą daleko idące skutki, doprowadzając do zawieszenia sześciu wyższych urzędników Magistratu oskarżanych między innymi o przyjmowanie łapówe ${ }^{28}$, co dostarczyło wystarczających argumentów za władczą ingerencją w ustrój lwowskiego samorządu. Opinia publiczna zdawała sobie sprawę z rychłego końca organów miejskich, prasa bowiem pisała już o proponowanych kandydatach na urząd komisarza rządowego, choć na ten temat nie wypowiedziało się jeszcze Ministerstwo Spraw Wewnętrznych ${ }^{29}$. Optowało ono za wstrzymaniem się od radykalnych rozwiązań i rozpisaniem wyborów na podstawie nowej ordynacji wyborczej. Inaczej widział to nowy wojewoda lwowski Piotr Dunin-Borkowski ${ }^{30}$, który ostatecznie przekonał ministra do rozwiązania Tymczasowej Rady Miejskiej¹. Decyzyjność w tej materii pozostawiono wojewodzie, uznając, że skoro Rada pochodziła z mianowania, to

ważności wyboru Prezydenta konieczna jest [...] bezwzględna większość głosów całej ilości członków [...] Rady". Przyjęto też, że w sytuacji gdy podczas pierwszego głosowania żaden z kandydatów nie uzyska wymaganej większości głosów, głosowanie będzie ponowione. Jeżeli za drugim razem sytuacja się powtórzy, wtedy będzie należało przeprowadzić wybór między dwoma kandydatami, którzy we wcześniejszym głosowaniu uzyskali najwięcej głosów. Radni głosowali między J. Neumannem (70 głosów) a Henrykiem Sawczyńskim (52 głosy), zatem głosowanie odbyło się zgodnie ze Statutem. Statut król.[ewskiego] [...], Lwów 1874, 93; Biedrzycka, Kalendarium, 15.

${ }_{22}$ Z.W. „W walce z dyktaturą magistracką. Rzekomy samorząd”, 5; „Rozpędzić Radę miejską!”, 5.

${ }^{23}$ Dz.U. 1920 nr 11 poz. 61.

${ }^{24}$ [Z.W.]. „W walce z dyktaturą magistracką. Nasza gwiazdka”, 10; Z.W. „W walce z dyktaturą magistracką. Jak Magistrat", 5 .

${ }^{25}$ Przemówienia, 13.

${ }^{26}$ Hrabyk, Wspomnienia, 543-544; Z.W. „W walce z dyktaturą magistracką. Plotki magistrackie”, 5.

27 „Co dzień niesie?”, 2; „Nasze pierwsze zwycięstwo”, 1.

${ }^{28}$ Biedrzycka, Kalendarium, 369.

29 „Pogłoski o rozwiązaniu Rady m. Lwowa”, 1.

${ }^{30}$ Biedrzycka, Kalendarium, 369; „Zmiana wojewody”, 2; „Powitanie nowego wojewody”, 1.

31 „Niefortunne zapędy lwowskiego wojewody”, 1. 
de facto była Radą Przyboczną, a J. Neumann komisarzem rządowym, zatem podlegali wojewodzie ${ }^{32}$.

Zgodnie z oczekiwaniami w dniu 31 sierpnia 1927 r. wojewoda lwowski rozwiązał Tymczasową Radę Miejską, przekazując władzę nad miastem Tymczasowemu Zarządowi Miejskiemu, w którego skład wchodzili komisarz Jan Strzelecki i jego zastępcy - Roman Frankowski oraz Maksymilian Matakiewicz ${ }^{33}$. Ich organem doradczym została powołana przez wojewodę 32-osobowa Rada Przyboczna ${ }^{34}$. Decyzja o rozwiązaniu Tymczasowej Rady Miejskiej była szeroko dyskutowana w kręgach politycznych. Socjaliści zastanawiali się nad legalnością mianowania komisarza rządowego, twierdząc, że akt ten wymagał zatwierdzenia dokonanego przez Tymczasowy Wydział Samorządowy ${ }^{35}$. Polska Partia Socjalistyczna (PPS) miała również zastrzeżenia co do działalności i składu Rady Przybocznej; widziała ją jako organ wyposażony w szersze kompetencje niż tylko opiniodawcze, wzmocniony przez jej reprezentantów ${ }^{36}$. Wojewoda przystał na takie warunki i podczas specjalnej konferencji zdecydowano o dodaniu Radzie nowych kompetencji - dotyczyły prawa budżetowania, nakładania podatków gminnych oraz sprawowania kontroli nad gospodarowaniem budżetem ${ }^{37}$. Zmianie uległ też skład Rady, została powiększona o dodatkowych 37 radnych, zgodnie z oczekiwaniami PPS ${ }^{38}$.

W związku z rozwiązaniem Tymczasowej Rady Miejskiej jej radni postanowili złożyć skargę do Najwyższego Trybunału Administracyjnego, który rozpatrzył sprawę dwa lata później, w 1929 r. ${ }^{39}$ Podczas rozprawy z 27 czerwca 1929 r. Tymczasową Radę Miejską reprezentowali: Rubin Sokal, członek byłej Rady, Marceli Chlamtacz, były wiceprezydent miasta, Herman Diamand oraz Jan Pieracki, lwowski adwokat ${ }^{40}$. Stronę pozwaną reprezentowali radca województwa lwowskiego Pawlikowski oraz przedstawiciel ministerstwa Kazimierz Windakiewicz, rozprawie zaś przewodniczył sędzia Juliusz Dunikowski ${ }^{41}$.

Rubin Sokal w swojej mowie przed Trybunałem odwołał się do podobnej sprawy rozwiązania reprezentacji gminnej Krakowa, która stanowiła już przedmiot rozprawy przed NTA ${ }^{42}$. Adwokat, porównując statuty Krakowa i Lwowa, próbował dowieść

32 „Ostatnie chwile Rady miasta Lwowa”, 1.

33 „Komisarz Strzelecki objął urzędowanie”, 1.

34 „Dekret o rozwiązaniu tymcz.[asowej] Rady m. Lwowa”, 1.

35 „Dekret o rozwiązaniu Rady m. Lwowa”, 1.

36 „P.P.S. wobec nowych rządów w ratuszu”, 1; „O głos decydujący mieszkańców Lwowa”, 1.

37 „Z życia miasta. Dekret o kompetencjach”, 7.

38 „Z życia miasta. Uzupełnienie Rady Przybocznej”, 7.

39 „Sprawa b. Rady miejskiej we Lwowie”, 1.

${ }^{40}$ Biedrzycka, Kalendarium, 479.

${ }^{41}$ „Sprawa b. Rady miejskiej we Lwowie”, 1.

${ }^{42}$ Decyzja wojewody o rozwiązaniu krakowskiej Rady Miejskiej 19 lipca 1924 r. odbiła się głośnym echem nie tylko w środowisku lokalnym, lecz także w Warszawie. Władze nadzorcze argumentowały swoją decyzję tym, że Rada nie była w stanie dokonać wyboru prezydenta, choć wydano ją tuż przed wyborami miejskimi. Wobec tego komisarzem rządowym został dotychczasowy wicewojewoda Zdzisław Wawrausch, któremu do pomocy przydzielono 36-osobową Radę Przyboczną. Decyzja wojewody budziła jednak wątpliwości natury prawnej, była bowiem niezgodna z postanowieniami Statutu, który w sytuacji rozwiązania Rady Miejskiej zakładał przejęcie obowiązków przez wiceprezydentów (gdy opróżniony był urząa prezydenta). Skłoniło to radnych do wniesienia skargi do NTA, który w orzeczeniu wyroku z dnia 26 kwietnia 1926 r. postanowił o uchyleniu decyzji wojewody z powodu wadliwego postępowania oraz niezgodności z ustawą. Zob. Dz. Urz. Woj. Kr. 5 (1924): 9; ANKr Krakowie, Akta miasta Krakowa, 
sprzeczności decyzji o rozwiązaniu lwowskiej Rady Miejskiej z obowiązującym wówczas prawem ${ }^{43}$. Swoje deliberacje zaczął od przytoczenia $\S 107$ Statutu mówiącego o rządowym prawie nadzoru nad gminą w celu dbałości o jej właściwy zakres działań zgodnie z ustawą. Trybunał (NTA), analizując sprawę krakowskiej Rady Miejskiej, stał na stanowisku, że prawo rozwiązania reprezentacji gminnej było „wypływem, ukoronowaniem i ostateczną sankcją prawa nadzoru władzy państwowej nad gminą"44, a co za tym idzie, rozwiązanie Tymczasowej Rady Miejskiej było nierozerwalnie związane $\mathrm{z}$ prawem do wykonywania nadzoru. W związku z tym obowiązywać miały takie same granice jak przy prawie nadzoru, co oznacza, że można było dokonać rozwiązania Rady tylko w sytuacji, gdyby ta wykroczyła poza zakres swoich kompetencji lub podjęła działania niezgodne $\mathrm{z}$ prawem ${ }^{45}$.

W uzasadnieniu reskryptu rozwiązującego Tymczasową Radę Miejską napisano: „wadliwości w administracji i gospodarce gminnej, wykazane przez lustrację, przeprowadzoną z ramienia TWS [Tymczasowy Wydział Samorządowy] we Lwowie w latach 1924 i 1926, nie zostały usunięte". Sokal zauważył, że władza nadzorcza mogła w takim wypadku skorzystać z innych dostępnych form nadzoru w postaci środków represji, jak na przykład grzywny, wprowadzenie środków zaradczych na koszt gminy lub wszczęcie postępowania dyscyplinarnego wobec prezydenta miasta. Władza nadzorcza nie skorzystała z tych środków, stosując od razu ten ostateczny, a co więcej, Tymczasowa Rada Miejska nie została poinformowana o rzekomych uchybieniach lub zaniedbaniach, jakich miały się dopuścić władze miejskie. Do tej kwestii odniósł się także M. Chlamtacz, wskazując na niezasadność decyzji wojewody lwowskiego, użyta argumentacja była bowiem sprzeczna z wnioskami zawartymi w raporcie pokontrolnym z 1926 r., w którym pozytywnie odniesiono się do pracy Magistratu ${ }^{46}$. Chlamtacz zauważył też, że ustalenia lustratorów z TWS różnią się od tych przedstawionych w 1927 r. przez kontrolerów ministerialnych. Powoływanie się na ich raport miało być błędne, gdyż ministerialna komisja lustracyjna „przekroczyła w swoich badaniach granice przyznanego władzy rządowej prawa nadzoru", ponieważ zarzuty, jakie stawiała, dotyczyły zadań własnych gminy, które nie powinny podlegać jej kontroli, a ewentualnie kontroli organu samorządowego wyższego stopnia ${ }^{47}$. Chlamtacz stwierdził wprost, że komisja ministerialna nie powinna być w ogóle powołana, bo było to niezgodne z ustawą. Podkreślił, że jej działalność „była sprzecznym z obowiązującym prawem naruszeniem prawa domowego gminy jako uprawnionego podmiotu władztwa administracyjnego"48. Uprawnienie do kontroli gospodarki miejskiej przysługiwało, w ograniczonym stopniu, Tymczasowemu Wydziałowi Samorządowemu ${ }^{49}$. Do tych samych wniosków doszedł R. Sokal, dodając, że komisja lustracyjna złamała zasady postępowania administracyjnego, ponieważ lu-

sygn. Kr 4422-4424, mps; Orzeczenie wyroku NTA (L. Rej.1325/25), [b.p.]; ANKr, Akta miasta Krakowa, sygn. Kr 4422-4424, mps; Protokół Rady Miejskiej z dnia 24 lipca 1924 r., [b.p.].

${ }^{43}$ Przemówienia, 4.

${ }^{44}$ Ibidem.

${ }^{45}$ Ibidem.

${ }^{46}$ Ibidem, 13.

47 Ibidem.

48 Ibidem, 29.

49 Ibidem. 
stratorzy powinni poprosić Prezydium Magistratu o wyjaśnienia w przypadku wykrycia nieścisłości ${ }^{50}$.

Dalsze wywody R. Sokala dotyczyły statusu Tymczasowej Rady Miejskiej. Urząd wojewódzki nazywał ją ,tymczasową Reprezentacją miasta, ustanowioną reskryptem Namiestnictwa z 21 stycznia 1918, a utrzymaną we funkcjach oraz rozszerzoną w składzie osobowym i kompetencji uchwała TKR [Tymczasowy Komitet Rządzący] z 11 stycznia 1919"51, inaczej zaś widzieli to jej pełnomocnicy, występujący przed NTA. Sokal poruszył także istotę problemu, a mianowicie to, czy rozwiązana Rada Miejska była pełnoprawnym organem uchwałodawczym, traktowanym jako organ statutowy. Adwokat zwrócił uwagę, że przez cały okres jej funkcjonowania zarówno mieszkańcy, jak i organy państwowe traktowały Radę jak pochodzącą z wyborów, tytułując ją Radą Miejską, a przedstawiciela władzy wykonawczej - prezydentem miasta. Argumentował przy tym, że Rada w okresie swojej aktywności podejmowała uchwały w sprawach zastrzeżonych dla pełnoprawnego organu - nakładała podatki, zaciągała pożyczki i decydowała o miejskich nieruchomościach ${ }^{52}$. Sokal zauważył także różnice między Tymczasową Radą Miejską powołaną przez namiestnika w 1918 r. a tą ustanowioną rok później, wskazując, że ta swoje źródło wywodzi z dekretu ustawodawczego, wydanego przez uprawniony do tego organ, jakim był TKR. Poza tym, ,gdyby [...] chodziło o zarządzenie administracyjne - nie o fakt ustawodawczy", zostałoby ono wydane przez pełniącego funkcję namiestnika wiceprezydenta Stanisława Grodzickiego ${ }^{53}$. Sokal odwołał się do opinii prawników, że ,ciągle wykonywanie jest formą powstania prawa przedmiotowego", dowodząc, że prawo zwyczajowe może być wykorzystane w prawie administracyjnym ${ }^{54}$. Wtórował mu M. Chlamtacz, który powołał się na wydarzenia związane z wyborem prezydenta J. Naumanna, kiedy jeden z radnych wniósł protest wyborczy. Namiestnictwo lwowskie wydało w tej sprawie reskrypt, w którym odrzuciło protest, zatem musiało dojść do jego rozpatrzenia. W rezultacie potwierdzono wybór J. Naumanna na urząd prezydenta Lwowa. Gdyby władze nadzorcze nie traktowały Tymczasowej Rady Miejskiej jako pełnoprawnego organu, to wniesiony protest pozostałby bez odpowiedzi, Rząd zaś miałby doskonałą sposobność do uznania Rady za Radę Przyboczną ${ }^{55}$.

Warto w tym miejscu podkreślić, że ze stanowiskiem R. Sokala nie zgadzała się część lwowskiej sceny politycznej, twierdząca, iż we Lwowie nie istniała pełnoprawna Rada Miejska, ponieważ jej członkowie nie pochodzili z wyborów, co więcej, uchwała TKR z 11 stycznia 1919 r. była sprzeczna z postanowieniami Statutu i ordynacją wyborczą. Roman Stupnicki w swoim komentarzu, zamieszczonym na łamach „Dziennika Lwowskiego", podkreślił, że uchwały tej nie należy traktować jak aktu ustawodawczego, nie został on bowiem należycie opublikowany w dzienniku urzędowym, którym była „Gazeta Lwowska”"56. W dniu 14 stycznia 1919 r. pojawił się tam jedynie „komunikat”,

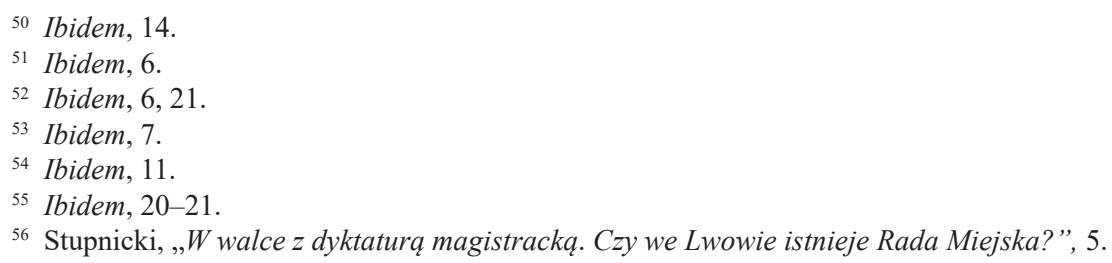


z którego można się było dowiedzieć o podjętej uchwale ${ }^{57}$. Autor podniósł także argument, że część składu Tymczasowej Rady Miejskiej została dokooptowana przez pozostałych jej członków, co czyniło Radę instytucją „nieśmiertelną”, bo opróżnione miejsce zawsze mogło zostać uzupełnione przez powołanych następców ${ }^{58}$. Ważnym argumentem był także fakt, że Statut jasno określał długość kadencji zarówno Rady, jak i członków Magistratu. W myśl przepisów po sześciu latach powinny były się odbyć wybory miejskie, zatem najpóźniej w 1925 r., do czego nie doszło. Tymczasem uspokajano opinię publiczną, że wybory zostaną przeprowadzone jak najszybciej po uchwaleniu nowej ordynacji wyborczej ${ }^{59}$. Warto $\mathrm{w}$ tym miejscu przypomnieć, że prace nad nią, prowadzone przez specjalną komisję, trwały prawie 10 lat, od 1918 r. do 25 marca 1927 r., kiedy to zakończono ten żmudny proces. Projekt nie został nawet wniesiony pod obrady Rady Miejskiej ${ }^{60}$.

W innym swym artykule R. Stupnicki podniósł jeszcze jeden argument, według którego uchwała TKR o powołaniu Tymczasowej Rady Miejskiej była pozbawiona mocy prawnej. Stwierdza on, że powstała 10 stycznia 1919 r. Komisja Rządząca dla Galicji, Śląska Cieszyńskiego, Spiszu i Orawy skasowała istniejący do tej pory TKR, który w związku z tym nie miał umocowania do wydawania aktów prawnych kolejnego dnia, jak się stało w przypadku powołania Tymczasowej Rady Miejskiej. Stupnicki powołał się przy tym na orzeczenie Sądu Najwyższego wydane w analogicznej sprawie, dotyczącej rozporządzenia TKR, wydanego 21 stycznia 1919 r. Sąd Najwyższy, badając tę sprawę w 1924 r., stwierdził, że akt ten był nieważny z powodu wydania go po 10 stycznia $1919 \mathrm{r}^{61}$

Do tych argumentów nie odniósł się swoim przemówieniu R. Sokal, który zmierzał do udowodnienia, że wojewoda, podejmując decyzję w sprawie rozwiązania Tymczasowej Rady Miejskiej, powinien wcześniej zasięgnąć opinii Tymczasowego Wydziału Samorządowego, podobnie jak wcześniej czynił to namiestnik w stosunku do Wydziału Krajowego ${ }^{62}$. M. Chlamtacz natomiast skoncentrował się w swoim wystąpieniu na próbie udowodnienia wadliwości aktu powołania ministerialnej komisji lustracyjnej oraz na wypunktowaniu popełnianych przez nią błędów i przekraczaniu uprawnień. Powołując się na stanowisko teoretyków prawa, zauważył, że gmina, choć jest „podmiotem pochodnym, to jednak «własnych i samodzielnych praw»”, zatem komisja lustracyjna naruszyła prawo podmiotowe gminy ${ }^{63}$.

Pełnomocnicy rozwiązanej Tymczasowej Rady Miejskiej wnioskowali o uchylenie decyzji wojewody jako sprzecznej z ustawą lub z powodu wadliwości postępowania administracyjnego, prosząc jednocześnie, aby orzeczenie NTA „było palladium i gwa-

57 „T.K.R., Komunikat”, 1; Z.W., „W walce z dyktaturą magistracką, Prawdziwa historia”, 5; R.S. [Roman Stupnicki], ,W walce z dyktaturą magistracką", 5.

58 Stupnicki, „W walce z dyktaturą magistracką. Czy we Lwowie istnieje Rada Miejska?”, 5.

59 R.S. [R. Stupnicki], „W walce z dyktaturą magistracką. XIX: Na wypadek rozwiązania Rady Miejskiej", 3 .

${ }^{60}$ Projekt ustawy miejskiej gminy król.[ewskiego] stot.[ecznego] miasta Lwowa, 1; Z.W., „W walce z dyktaturą magistracką. Lustracja T.W.S”, 3 .

${ }^{61}$ R.S. [R. Stupnicki], „W walce z dyktaturą magistracką. XVI: Sąd Najwyższy a Tymczasowa Rada miejska", 5.

62 Przemówienia, 12.

63 Ibidem, 29. 
rancją zasady [...], że «wolna gmina jest podstawą, ostoją i twierdzą wolnego i silnego państwa»" ${ }^{" 64}$. Były wiceprezydent Lwowa M. Chlamtacz powiedział także:

Iustitia - Najwyższy Trybunale! - est constans et perpetua voluntas ius suum cuique tribuendi. Powtarzam cuique, gdyż przez moje usta domaga się zespół obywateli rozwiązanej Rady, domaga się b. Prezydium restytucji niesłusznie sponiewieranej czci i osobistego dostojeństwa, które były jedyną nagrodą za sprawowanie rządów miasta w czasach najtrudniejszych; przez moje usta domaga się gmina lwowska restytucji niesłusznie utraconego samorządu ${ }^{65}$.

Wyrok w sprawie zapadł 28 listopada 1929 r. (L. Rej. 4126/27) i dotyczył braków formalnych decyzji rozwiązującej Tymczasową Radę Miejską. Wykazano bowiem, że w jej treści nie zawarto informacji o możliwości wniesienia odwołania, a władza pozwana ,wydając mylne pouczenie o środkach prawnych, naruszyła formy postępowania administracyjnego ze szkodą dla skarżącego"66. Uchylenie wadliwej decyzji wojewody lwowskiego rodziło obowiązek wydania przez niego nowego rozporządzenia w ciągu 30 dni od doręczenia wojewodzie wyroku, zatem nie ingerowano w kształt ustrojowy lwowskiego samorządu, pozostawiając komisarza i Radę Przyboczną na swoich stanowiskach ${ }^{67}$. Władze nadzorcze miały zatem możliwość pozostawienia ówczesnego status quo, przywrócenia Tymczasowej Rady Miejskiej i następnie jej rozwiązania albo powołania jej w takim kształcie, że część radnych pochodziła z wyborów przeprowadzonych jeszcze przed I wojną światową, część zaś z kooptacji. W związku z tym rozpoczęły się gorączkowe zabiegi byłych radnych o przywrócenie dawnej Rady Miejskiej. Pierwsza delegacja udała się do wojewody lwowskiego, ten jednak stwierdził, że związany jest instrukcjami władz centralnych ${ }^{68}$, dlatego zdecydowano się na wyjazd do Warszawy, aby tam walczyć o restytucję dawnych organów gminy ${ }^{69}$. Posłowie Bezpartyjnego Bloku Współpracy z Rządem (BBWR), zasiadający w sejmowej Komisji Administracyjnej, stwierdzili, że Lwów zasługuje na przywrócenie samorządu i zmianę statutu miejskiego ${ }^{70}$, a podobną opinię wyrażało także MSW, skąd wypłynęła propozycja, aby reaktywować dawną Radę Miejską ${ }^{71}$. Działo się to równocześnie z pracami nad ustawą o reprezentacji gminnej i ordynacji wyborczej dla Małopolski, która czyniłaby zadość oczekiwaniom części samorządowców dążących do przeprowadzenia demokratycznych wyborów miejskich. Dostrzeżono jednak problem natury narodowościowej, ponieważ obawiano się, że wprowadzenie pięcioprzymiotnikowej ordynacji wyborczej we wschodniej Małopolsce mogłoby „wyrządzić istotnie poważną szkodę państwowości polskiej"72.

Ministerstwo Spraw Wewnętrznych traktowało ten argument poważnie, skoro zdecydowano się przystać na propozycje wysuwane przez delegację byłych radnych. W maju

${ }^{64}$ Ibidem, 15.

65 Ibidem, 33.

${ }^{66}$ „Wobec rozstrzygnięcia NTA”, 4; „Uzasadnienie orzeczenia Najw.[yższego] Tryb.[unału] Admin. [istracyjnego]", 3 .

67 „Uzasadnienie orzeczenia Najw.[yższego] Tryb.[unału] Adm.[inistracyjnego]”, 3.

68 „W sprawie samorządu Lwowa”, s. 2.

69 „Na drodze przywrócenia samorządu lwowskiego", 6.

70 „BBWR i Rząd oświadczają się za samorządem Lwowa i Małopolski”, 1-2.

71 „Powrót dawniejszej Rady Miejskiej we Lwowie”, 3.

72 „Próby wypaczenia samorządów”, 3; „O samorządową ordynację wyborczą we Wsch.[odniej] Małopolsce", 1. 
1930 r. poinformowano opinię publiczną o planach przywrócenia dawnej Rady Miejskiej, której część radnych zostało wybranych jeszcze w 1913 r. Opróżnione miejsca miały być uzupełniane przez mianowanie nowych radnych, z uwzględnieniem interesu wszystkich grup politycznych, gospodarczych i narodowościowych Lwowa ${ }^{73}$. Po tej deklaracji ministra 24 maja 1930 r. wojewoda lwowski wydał decyzję, na mocy której wprowadzono Tymczasową Radę Miejską, liczącą 130 radnych. Upływ czasu sprawił, że z pierwotnego stanu Rady mandat mogło objąć 36 osób wybranych w 1913 r., pozostałych zaś mianował wojewoda. Czynić miał to także w sytuacji opróżnienia miejsca, na wniosek Rady, z grona osób pochodzących ze środowiska, do którego należał odchodzący radny.

W dniu 5 czerwca $1930 \mathrm{r}^{74}$ przeprowadzono wybory do Prezydium Magistratu, wraz z czym ukonstytuowała się Rada Miejska, a ustępował komisarz i jego Rada Przyboczna $^{75}$. Głosowanie zostało poprzedzone wystąpieniami przedstawicieli klubów politycznych, którzy wygłosili swoje deklaracje. Wydaje się, że entuzjazmu z przywrócenia Rady Miejskiej w takiej formie nie podzielali sami radni, którzy otwarcie krytykowali ingerencję władzy nadzorczej w skład osobowy Rady ${ }^{76}$. Wybory na prezydenta były doskonałą okazją do zamanifestowania swojego niezadowolenia, dlatego aż 27 radnych oddało białą kartkę. Większość opowiedziała się jednak za Janem Brzozowskim-Haluchem, który przyjął zaszczytny urząd Prezydenta ${ }^{77}$.

Historia lwowskiego samorządu $\mathrm{z}$ lat dwudziestych XX w. doskonale obrazuje politykę obozu rządzącego względem organów miejskich, wykorzystującego nadarzającą się okazję do wzmocnienia swej pozycji. Wyrok NTA pozostawiał wojewodzie możliwość poprawienia błędu formalnego i wydania rozporządzenia utrzymującego w mieście władze komisaryczne, z czego ten jednak nie skorzystał. Wydaje się, że był to rezultat kalkulacji możliwych zysków i strat. Stało się zadość idei samorządności (choć w niepełnym stopniu), a także oczekiwaniom części środowiska politycznego oraz jednocześnie (i prawdopodobnie przede wszystkim) zadbano o interes BBWR. Rząd doskonale zdawał sobie sprawę z tego, że niewielu radnych wybranych przed I wojną światową obejmie mandat po reaktywacji Rady Miejskiej. Opróżnione miejsca zajęły osoby nastawione prorządowo, co było gwarantem wyboru właściwego kandydata na urząd Prezydenta. Na początku lat trzydziestych stało się też oczywiste, że wcześniejsze plany objęcia Lwowa osobną ustawą nie zostaną urzeczywistnione, a ustawa scaleniowa wkrótce zostanie uchwalona i na podstawie nowej ordynacji przeprowadzone zostaną wybory miejskie, które przypieczętują ugruntowaną pozycję BBWR we Lwowie. Przewidywania polityków sprawdziły się. W wyborach z 1934 r. siły prorządowe zdobyły 45 z 72 miejsc w Radzie ${ }^{78}$.

73 „Min. Józewski o Radzie Miejskiej Lwowa i stanie naszych województw”, s. 1.

${ }^{74}$ We współczesnych opracowaniach pojawia się informacja, że wybory prezydenta Lwowa przeprowadzono 5 czerwca 1930 r., jednak w artykułach prasowych dzienników datowanych na 7 czerwca pisano, że wybory odbyły się „wczoraj”, więc w dniu 6 czerwca 1930 r. Zob. U ratuszi, 52; Biedrzycka, Kalendarium, 525; por. też: „Pierwsze posiedzenie mianowanej Rady Miejskiej”, 3; „Inż. Brzozowski prezydentem Lwowa", 2.

75 „Rekonstrukcja samorządu lwowskiego”, 4-5; „Wznowienie samorządu m. Lwowa”, 5.

76 „Pierwsze posiedzenie mianowanej Rady Miejskiej”, 3; „Inż. Brzozowski prezydentem Lwowa”, 4.

77 Ibidem.

${ }^{78}$ „Ostateczny wynik wyborów do Rady Miejskiej”, 1. 


\section{Bibliografia}

\section{Źródła archiwalne}

Archiwum Narodowe w Krakowie [ANKr], Akta miasta Krakowa, sygn. Kr 4422-4424.

Archiwum Narodowe w Krakowie [ANKr], Akta miasta Krakowa (nr 33).

Państwowe Archiwum Obwodu Lwowskiego, Magistrat miasta Lwowa, fond 2.

\section{Źródła drukowane}

Dziennik Ludowy. Roczniki: 1927, 1930.

Dziennik Lwowski. Roczniki: 1926, 1927, 1929, 1930.

Gazeta Lwowska. Roczniki: 1918, 1919, 1927.

Projekt ustawy miejskiej gminy król.[ewskiego] stoł.[ecznego] miasta Lwowa, Lwów 1927.

Przemówienia dr. Rubina Sokala [...]. Lwów 1929.

Sprawozdanie z czynności Zarządu Król.[ewskiego] Stoł.[ecznego] Miasta Lwowa za czas od 1. lipca 1915. do 31. grudnia 1916. Lwów 1917.

Statut król.[ewskiego] miasta Lwowa. Nadany ustawą z dnia 14 października 1870 r. Lwów 1874.

Statut król.[ewskiego] stoł.[ecznego] m.[iasta] Lwowa. Lwów 1930.

\section{Źródła prawne}

Dziennik Urzędowy Województwa Krakowskiego [Dz. Urz. Woj. Kr.] 1924.

Dziennik Ustaw Rzeczypospolitej Polskiej. Roczniki: 1920, 1921.

Orzeczenie wyroku Najwyższego Trybunału Administracyjnego (L. Rej. 1325/25).

Protokół Rady Miejskiej z dnia 24 lipca 1924 r., Archiwum Narodowe w Krakowie, Akta miasta Krakowa, sygn. Kr 4422-4424, [b.p.].

Rozporządzenie Rady Ministrów z dnia 17 maja 1921 r. w przedmiocie wykonania art. 3 ustawy z dnia 3 grudnia 1920 r. o tymczasowej organizacji władz administracyjnych II instancji (województw) na obszarze b. Królestwa Galicji i Lodomerji z W. Ks. Krakowskiem oraz na wchodzących w skład Rzeczypospolitej Polskiej obszarach Spisza i Orawy (Dz.U. 1921 nr 46 poz. 282).

\section{Opracowania}

Białynia Chołodecki, Józef. Zakładnicy miasta Lwowa w niewoli rosyjskiej 1915-1918. Z fotograficzna odbitka zakładników. Lwów: Redakcja z zasiłkiem Reprezentacji król.[ewskiego] stoł.[ecznego] miasta Lwowa, 1930.

Biedrzycka, Agnieszka. Kalendarium Lwowa 1918-1939. Kraków: Towarzystwo Autorów i Wydawców Prac Naukowych Universitas, 2012.

Bohdan, Janusz. 293 dni rządów rosyjskich we Lwowie (3. IX. 1914 - 22. VI. 1915). Lwów: Księgarnia Polska (Bernarda Połonieckiego); Warszawa: Gebethner i Wolff, 1915.

Hołuj, Dominika. „Samorząd miejski Krakowa i Lwowa w okresie autonomii galicyjskiej”. Zeszyty Naukowe Uniwersytetu Ekonomicznego w Krakowie 917 (2013): 89-108. 
Hrabyk, Klaudiusz. „Wspomnienia. Część III”. Rocznik Historii Czasopiśmiennictwa Polskiego 9/4 (1970), 543-571.

Kulmatycki, J.B. Rada miasta Lwowa 1913-19. Lwów [b.d.w.].

Ostaszewski-Barański, Kazimierz. „Ustawa Prowizoryczna (1848-1870)”. W: Miasto Lwów w okresie samorzadu 1870-1895, opr. Mieczysław Baranowski [et al.]. Lwów: nakładem Gminy Król.[ewskiego] Stoł.[ecznego] Miasta Lwowa, 1896.

U ratuszi mista Lvova [...]. Wid burmistriw do miskich holiv. Lviv, 2016.

\section{Artykuły prasowe}

„BBWR i Rząd oświadczają się za samorządem Lwowa i Małopolski”. Dziennik Lwowski nr 23 z 24 I 1930.

„Co dzień niesie? Z Rady miejskiej”. Gazeta Lwowska nr 11 z 15 I 1927.

„Dekret o rozwiązaniu Rady m. Lwowa”. Dziennik Ludowy nr 199 z 2 IX 1927.

„Dekret o rozwiązaniu tymcz.[asowej] Rady m. Lwowa”. Gazeta Lwowska nr 200 z 2 IX 1927.

„Inż. Brzozowski prezydentem Lwowa”. Dziennik Lwowski nr 154 z 7 VI 1930.

„Inż. Brzozowski prezydentem Lwowa”. Dziennik Lwowski nr 154 z 7 VI 1930.

„Komisarz Strzelecki objął urzędowanie”. Gazeta Lwowska nr 202 z 4 IX 1927.

„Kronika. W biurze wiceprezydenta dra Filipa Schleichera [...]”. Gazeta Lwowska nr 1 z 1 I 1918.

„Min. Józewski o Radzie Miejskiej Lwowa i stanie naszych województw”. Dziennik Lwowski nr 127 z 11 V 1930.

„Na drodze przywrócenia samorządu lwowskiego”. Dziennik Ludowy nr 8 z 12 I 1930.

„Nasze pierwsze zwycięstwo w walce z dyktaturą magistracką! Rada miejska zmuszoną została do ustąpienia! - Dalszy etap walki. Pod sąd z p. Neumannem”, „Dziennik Lwowski” nr 23 z 15 II 1927.

„Niefortunne zapędy lwowskiego wojewody. Zamiast wyborów do Rady m. Lwowa - komisarz rządowy. Pierwszy fatalny krok nowego wojewody lwowskiego". Dziennik Ludowy nr 186 z 18 VIII 1927.

„O głos decydujący mieszkańców Lwowa w zarządzie miasta”. Dziennik Ludowy” nr 204 z 8 IX 1927.

„O samorządową ordynację wyborczą we Wsch.[odniej] Małopolsce”. Dziennik Lwowski nr 59 z 1 III 1930.

„Ostateczny wynik wyborów do Rady Miejskiej”. Ilustrowany Goniec Wieczorny nr 17 z 28 V 1934.

„Ostatnie chwile Rady miasta Lwowa. Interpelacja klubów w sprawie min. komisji lustracyjnej. W przededniu rozwiązania Rady miejsk.[iej] Lwowa". Dziennik Ludowy nr 188 z 20 VIII 1927.

„P.P.S. wobec nowych rządów w ratuszu”. Dziennik Ludowy nr 202 z 5 IX 1927.

„Pierwsze posiedzenie mianowanej Rady Miejskiej”. Dziennik Ludowy nr 158 z 7 VI 1930.

„Pierwsze posiedzenie mianowanej Rady Miejskiej”. Dziennik Ludowy nr 158 z 7 VI 1930.

„Pierwsze posiedzenie mianowanej Rady Miejskiej”. Dziennik Ludowy nr 158 z 7 VI 1930.

„Pogłoski o rozwiązaniu Rady m. Lwowa”. Gazeta Lwowska nr186 z 17 VIII 1927.

„Powitanie nowego wojewody”. Gazeta Lwowska nr 187 z 18 VIII 1927.

„Powrót dawniejszej Rady Miejskiej we Lwowie”. Dziennik Ludowy nr 12 z 17 I 1930.

„Próby wypaczenia samorządów”. Dziennik Ludowy nr 33 z 10 II 1930.

„Rekonstrukcja samorządu lwowskiego”. Dziennik Ludowy nr 119 z 26 V 1930.

„Rozpędzić Radę miejską! Nie potrzeba samorządów!”. Dziennik Ludowy nr 4 z 6 I 1927.

„Rozporządzenie”. Gazeta Lwowska nr 256 z 29 XI 1918. 
„Sprawa b. Rady miejskiej we Lwowie”. Dziennik Lwowski nr 175 z 29 VI 1929.

„T.K.R. Komunikat”. Gazeta Lwowska nr 10 z 14 I 1919.

„Tymczasowa Rada Miejska we Lwowie”. Gazeta Lwowska nr 31 z 7 II 1918.

„Uzasadnienie orzeczenia Najw.[yższego] Tryb.[unału] Adm.[inistracyjnego] w sprawie Rady Miejskiej we Lwowie". Dziennik Lwowski nr 320 z 1 XII 1929.

„Uzasadnienie orzeczenia Najw.[yższego] Tryb.[unału] Admin.[istracyjnego]. W sprawie Rady miejskiej we Lwowie". Dziennik Lwowski nr 320 z 1 XII 1929.

„W sprawie samorządu Lwowa”. Dziennik Ludowy nr 6 z 6 I 1930.

„Wobec rozstrzygnięcia NTA”. Dziennik Lwowski nr 319 z 30 XI 1929.

„Wznowienie samorządu m. Lwowa”. Dziennik Lwowski nr 142 z 26 V 1930.

„Z życia miasta. Dekret o kompetencjach Rady Przybocznej m. Lwowa ukaże się w dniach najbliższych”. Dziennik Lwowski nr 272 z 25 IX 1927.

„Z życia miasta. Uzupełnienie Rady Przybocznej. Powołanie 37 nowych członków”. Dziennik Lwowski nr 328 z 20 XI 1927.

„Zarząd miasta Lwowa. Ogłoszenie”. Gazeta Lwowska nr 8 z 11 I 1919.

„Zmiana wojewody”. Dziennik Ludowy nr 189 z 28 VII 1927.

R.S. [Roman Stupnicki]. „W walce z dyktaturą magistracką. XIX: Na wypadek rozwiązania Rady Miejskiej. Prezydium miasta urzędować nie ma prawa”. Dziennik Lwowski nr 19 z 11 I 1927.

R.S. [Roman Stupnicki]. „W walce z dyktaturą magistracką. XVI: Sąd Najwyższy a Tymczasowa Rada miejska. Rada miejska istnieje bezprawnie”. Dziennik Lwowski nr 16 z 8 I 1927.

R.S. [Roman Stupnicki]. „W walce z dyktaturą magistracką. XVI: Sąd Najwyższy a Tymczasowa Rada miejska. Rada miejska istnieje bezprawnie". Dziennik Lwowski nr 16 z 8 I 1927.

Stupnicki, Roman. „W walce z dyktaturą magistracką. Czy we Lwowie istnieje Rada Miejska?”. Dziennik Lwowski nr 3 z 24 XII 1926.

Stupnicki, Roman. „W walce z dyktaturą magistracką. Czy we Lwowie istnieje Rada Miejska?”. Dziennik Lwowski nr 3 z 24 XII 1926.

[Z.W.]. „W walce z dyktaturą magistracką. Nasza gwiazdka dla samozwańczych rządców miasta”. Dziennik Lwowski nr 4 z 25 XII 1926.

Z.W. „W walce z dyktaturą magistracką. Jak Magistrat szafował zaliczkami z funduszów miejskich?”. Dziennik Lwowski nr 8 z 31 XII 1926.

Z.W. „W walce z dyktaturą magistracką. Lustracja T.W.S. czynności Prezydium. Pan prez.[ydent] Neumann sabotuje reformę ordynacji wyborczej”. Dziennik Lwowski nr 5 z 28 XII 1926.

Z.W. „W walce z dyktaturą magistracką. Plotki magistrackie”. Dziennik Lwowski nr 9 z 1 I 1927.

Z.W. „W walce z dyktaturą magistracką. Prawdziwa historia nieprawdziwej Rady Miejskiej”. Dziennik Lwowski nr 2 z 23 XII 1926.

Z.W. „W walce z dyktaturą magistracką. Rzekomy samorząd miasta Lwowa”. Dziennik Lwowski nr 1 z 22 XII 1926. 